\title{
Resenhas
}

\section{Metamorfoses políticas no Brasil oitocentista}

\section{Janaina Cardoso de Mello}

MOREL, Marco. As transformações dos espaços públicos. Imprensa, atores politicos e sociabilidades na cidade Imperial (1820-1840). São Paulo: Hucitec, 2005. 326p.

O percurso das metamorfoses políticas responsáveis pelas transformações dos espaços públicos adentrando a livraria de Pierre Plancher, localizada na Rua do Ouvidor 95, inicia a jornada dessa obra sobre o Brasil oitocentista.

A Tese de Doutorado de Marco Morel, professor Adjunto de História do Brasil da UERJ, defendida em 1995 na Universidade de Paris I (Panthéon - Sorbonne), sob a orientação de François-Xavier Guerra, torna-se referência fundamental para a compreensão das “identidades políticas" em meio às manifestações populares, lojas maçônicas e manuscritos.
Há algum tempo o autor já adoça o paladar dos interessados no conhecimento de uma cultura política híbrida apoiada nas múltiplas vertentes liberais vinculadas ao ideário das Revoluções Francesas, Inglesas e das Independências Americanas, ao compartilhar suas idéias em artigos como Papéis incendiários, gritos e gestos (2002), livretos como Frei Caneca: entre Marilia e a pátria (2000); Palavra, imagem e poder (2003), e obras mais densas como Cipriano Barata na Sentinela da Liberdade (2001).

A opção teórica por uma história política associada ao papel desempenhado pelos agentes históricos sublinha sua formação no bojo das leituras de Jurgen Habermas, Reinhart Koselleck, Pierre Rosanvanllon, Roger Chartier, Daniel Roche, Maurice Agulhon, Arlette Farge, sem contudo deixar de lado 
as especificidades das Américas Ibéricas apreendidas junto aos trabalhos de François-Xavier Guerra.

Caminho este percorrido significativamente por outros historiadores como José Murilo de Carvalho, Ilmar Holoff de Mattos, Gladys Sabina Ribeiro, Lúcia Maria Bastos, Lúcia Maria Guimarães e Marcello Basile, que, embora privilegiem outras discussões, tornaram-se expoentes do pensamento político oitocentista na cidade do Rio de Janeiro.

As discussões a respeito do processo de edificação da nação apontam para a organização de uma cultura literária trazida na bagagem de um bonapartista cujo comércio cruzava-se com as atividades da elite letrada preocupada em construir os arcabouços do Estado brasileiro (p.25). Pela livraria de Plancher circulavam idéias, pessoas e personagens ficcionais como Brás Cubas de Machado de Assis. "Instruir o público e ganhar dinheiro!" Esses eram os pressupostos do editor francês, cujas publicaçóes oriundas de sua terra natal pregavam o exorcismo do espírito revolucionário, a pacificação das ações e a manutenção salutar do ordenamento governamental ao estilo de François Guizot. Desenvolvia-se dessa forma uma es- fera pública literária aliada de uma lógica política que reproduzia as afinidades ideológicas entre as atividades privadas e o Estado (p.57).

A construção da opinião na cidade imperial e as múltiplas formas de sociabilidade conformam uma contextura dos espaços públicos que coloca na ordem do dia grupos liberais exaltados, moderados e restauradores analisados a partir de variadas fontes compostas de memórias, relatórios diplomáticos, correspondências, manifestos, cartografia, periódicos e panfletos que integram importantes acervos documentais em Paris e no Rio de Janeiro.

Sem tornar-se prisioneiro do lugar comum, Morel nos brinda com a elucidação de conceitos e palavras como liberalismo descortinado sob a unidade de um mesmo vocabulário que revela uma heterogeneidade de sentidos, de acordo com os deslocamentos no tempo, espaço geográfico e lugar social. (p.48). Aborda a noção de partido, percebendo novos sujeitos políticos em busca da organização das práticas de poder no nascente ambiente de uma modernidade política onde a idéia de fragmentação ameaçava o Brasil pós-independente, processo semelhante ao termo classe expon- 
do um dualismo semântico que ora aproximava-se da antiga noção de corpos sociais e ora evocava contradições e conflitos sociais apreendidos dos estudos de economia política francesa e inglesa liberal dos anos de 1820. Arcaica ou moderna, ambas as visões de classe sofriam o hibridismo tão peculiar da sociedade brasileira e direcionavam-se para a preocupação com a integridade nacional (p.66). Morel não se esquivou à discussão das três soberanias (rei, povo e nação) defendidas pelos grupos restauradores, exaltados e moderados, tendo por princípio a idéia de soberania como relações de poder, nas quais as decisóes perpassam tensões entre o governo e as forças políticas e sociais (p.67). A exposição desses termos adequados em sua significação ao período sob enfoque torna possível evitar os costumeiros anacronismos dos amantes do século XX.

$\mathrm{O}$ autor analisa ainda as metáforas zoológicas utilizadas no jogo político e divulgadas pela imprensa do Rio de Janeiro, nas quais a docilidade vinculada ao patriotismo representava uma conduta positiva oposta à ferocidade entendida como defeito de caráter e comportamento políticos. Assim, o uso de alcunhas serve para desqualificar os ad- versários políticos chamados de "galinhas de guiné" (aos partidários de Cipriano Barata), "tigres", "macacos", "cães", "feras", "beija-flor" (neste caso, valorativo), "bodes", além de referências à monstruosidade: corcundas, os inimigos do constitucionalismo liberal, transmigrada de Portugal, cuja simbologia política foi trabalhada em obra recente pela professora Lúcia Bastos Pereira das Neves (2003).

Ao trabalhar a cartografia francesa, o autor clarifica a intencionalidade presente no desenho de um "Brasil harmônico", construído como representação de coesão, centralizado pelo eixo Rio de JaneiroBahia, conformando hierarquias políticas e administrativas onde reinava a cidade imperial. Porém, descortina essa "falsa aparência" ao mostrar os quarteirôes do comércio como lócus da agitação urbana, ocupado por grupos envoltos em questões políticas e manifestações públicas antilusitanas fora do controle do poder monárquico, suscitando ameaças à ordem instituída. Compõem ainda esse cenário as batalhas jurídicas em 1830 para uso formal das ruas e praças como lugar de manifestação cívica, fora da iniciativa oficial, cujos conflitos indicam formas distintas de sociabilidades ur- 
banas: uma tradicional, com cerimônias religiosas ou festas de corporações, e outra inaugurada pela modernidade política na perspectiva de indivíduos livres (cidadãos) se reunirem em público expressando a soberania nacional ou popular (p.161).

O papel do panfletário ou jornalista (redator ou gazeteiro) conduzindo uma imprensa de opinião, difundindo idéias e embates que balizam o exercício da palavra num espaço que não se confundia com o Estado, uma vez que este buscava reprimir e controlar o ambiente cultural (p.171), possibilita a inteligibilidade da noção de opiniāo pública em sua polissemia, porém com contornos característicos no oitocentos. Assim, esse conceito é compreendido como recurso para legitimação de práticas políticas, como operação simbólica de transformar opiniōes individuais ou setoriais em opinião geral (p.200).

As transformações na cena pública, onde as maneiras de conceber os espaços de fazer política - no âmbito da polis - se alteram, inovando no surgimento de uma imprensa periódica de opinião, de associações leigas e não diretamente vinculadas à administração pública legitimando determinadas liberda- des e suas restrições (p.223), articulam-se a outras formas de apropriação da espacialidade na cidade imperial a partir da reflexão do papel desempenhado pelas atividades maçônicas, presentes na origem da efetivação de práticas políticas democráticas (p.241).

Também as associações de estrangeiros, agremiaçōes corporativas, a Sociedade Auxiliadora da Indústria Nacional (destacando-se por seu desempenho político, econômico e cultural) geradora do Instituto Histórico e Geográfico Brasileiro (IHGB) e Instituto Fluminense de Agricultura, a Sociedade de Medicina do Rio de Janeiro e as sociedades secretas federalistas estão relacionadas às complexas teias e mediações de sociabilidades formais e informais compostas por diversidades sociais ou étnicas, produtoras de falas que saíam do âmbito privado para os impressos ou ruas do Rio de Janeiro. Palavras incendiárias, mas, sobretudo transformadoras das relações espaciais entre os grupos sociais. Salve o oitocentos! 